\title{
Development of Student Worksheet Based on Ethnomathematics Traditional Engklek Games on Cube and Rectangular Pyramid
}

\author{
Mar'atush Sholihah ${ }^{1, *}$ Soffil Widadah ${ }^{1,}$ Dewi Sukriyah ${ }^{1}$
}

\author{
${ }^{1}$ STKIP PGRI Sidoarjo \\ *Corresponding author. Email: soffdah16@gmail.com
}

\begin{abstract}
The math learning associated with traditional games will make students learn while playing, but unfortunately not many teachers have developed learning devices related to ethnomathematics. The purpose of this study is to describe the process and result of the development of student's worksheet based on ethnomathematics traditional Engklek game on cube and rectangular pyramid. This research is development research with a Plomp development model with four steps namely: Preliminary investigation, Design, Realization, and Test, evaluations, and revisions. This research used five $8^{\text {th }}$ graders. The result of the research: (1) based on valid criteria of student worksheet developed were declared result average score of 4,27 (very valid), (2) student worksheet by practical criteria with the average rating of the validator stating the student worksheet can be used with a little revision and obtained a percentage of learning management implementation $88,9 \%\left(1^{\text {st }}\right.$ meeting) and $85 \%\left(2^{\text {nd }}\right.$ meeting) of the 18 existing phases, so that the worksheet developed is considered practical because the percentage of implementation is more than $75 \%$. Learning management obtained a final average score of 3.44 (good). In addition, based on student activity, active activity was generated by $92.7 \%$ while passive activity was $8.2 \%$., so it can be concluded that student worksheet is very practical to use, (3) based on the learning achievement test obtained $80 \%$ classical completeness (good) with an average grade obtained 88 , while the result of student questionnaire responses obtained a score of $98 \%$ (very positive), so it can be concluded that student worksheet developed effectively used.
\end{abstract}

Keywords: Student Worksheet, Ethnomathematics, Traditional Engklek Game.

\section{INTRODUCTION}

The occurrence of cultural changes from traditional to modern times, if it is neglected, will result in a cultural crisis that is traditional. According to Rofik \& Sudar (2015) [1], a cultural crisis can be overcome by fixing education through efforts to develop an attitude of respecting culture through the educational process. Through culture the educational process grows, because culture is the work of human creation, the educational process cannot be separated from the cultural process. The education process in Indonesia is carried out from elementary to high school with one of the educational processes through mathematics.

In general, mathematics is considered difficult for students, even answering as a scary subject. This is evident when researchers teach tutoring, where some students answer the same thing that the reason students find mathematics difficult and scary is that students do not understand the concepts and applications of mathematics in everyday life. According to Auliya (2016) [2], mathematics is a difficult subject, because mathematics is abstract, logical, systematic, and full of extraordinary symbols and formulas.

Responding to this, we need something that can connect mathematics with the environment outside of school. One appropriate way is to take advantage of the ethnomathematics approach to the learning process. According to Rosa (2016) [3], the ethnomathematical theory will grow through learning with traditional elements that contain history, this means that ethnomathematics is a form of mathematics learning approach that links local cultural wisdom. Through ethnomathematics, mathematical concepts can be studied in cultural practice. In addition, students better understand the relationship between culture and 
mathematics and teachers can instill cultural values that have an impact on the development of character education for students.

According to Marsigit (2016) [4], ethnomathematics is a science used to understand how mathematics is adapted from culture and functions to express the relationship between culture and mathematical activities. The activity in question is an activity in which there is a process of abstracting everyday life with mathematics, which shows that mathematical concepts have been applied by society in the past and are applied in cultural concepts.

The results of interviews and observations of mathematics learning in class $8^{\text {th }}$ grade at one of the junior high schools in Sidoarjo Indonesia, the teacher still uses conventional learning models such as the lecture and question and answer method which means that the learning process is teacher-centered as a source of information, which requires Pathi \& Belbase (2017) [5] which states that Most of the learning process carried out by the teacher is conventional learning, namely the method of lecturing, question and answer, and presenting assignments so that the learning process seems boring. This has an impact on student achievement scores on the material surface area which is classified as low. The low student learning achievement can be seen from the average mathematics score of class $8^{\text {th }}$ at the school, which is 70 while the minimum completion criteria are set at 75 .

Responding to matters concerning ethnomathematics and student problems in the material of flat-sided shapes, it is necessary to have a culture that can withstand the flat-sided shape, one of which is the Engklek. With this Engklek game, students are expected to be able to learn while playing so that students can easily understand the material for building flat sides. With this Engklek game, students not only learn but also get to know Indonesian culture. Engklek is a traditional game that is well known in Indonesia and is still played by children. According to Muzdalifah \& Yulianto (2015) [6], Engklek is a traditional game of jumping on plots in the form of a flat area that has been given a checkered pattern, then using one leg from one plot to the next. Map the Engklek if observed takes a flat-sided space network because this researcher uses the Engklek of mathematical objects.

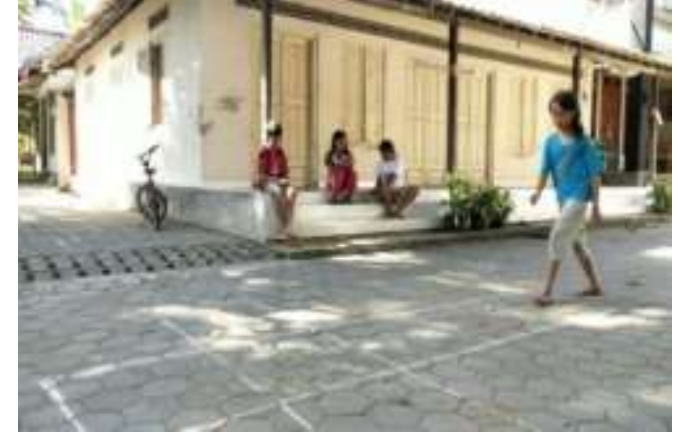

Figure 1 Children Play Airplane Engklek.

This Engklek game can be used as an ethnomathematical object by directing students to form a modified image in a predetermined way without eliminating ethnomathematics. Here is a picture of an airplane Engklek.

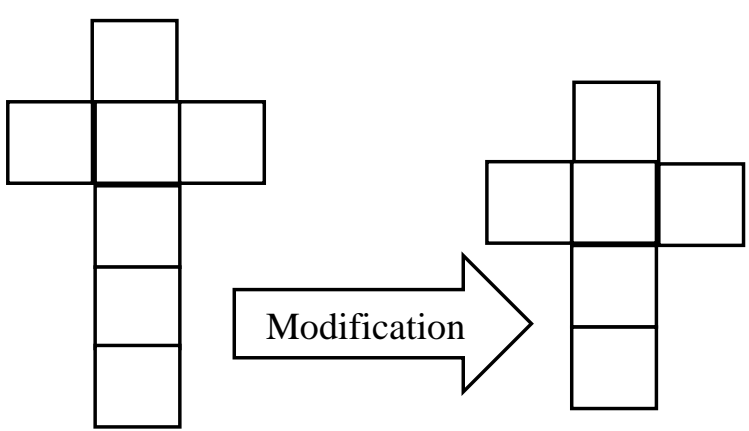

Figure 2 Airplane Engklek.

Figure 2 shows that the airplane's Engklek image is modified by assuming the first tile is missing which aims as a first step in determining the surface area of a cube through an Engklek that resembles a grid of cubes. Apart from airplane Engklek, there are propeller Engklek that can be used for learning mathematics [10].

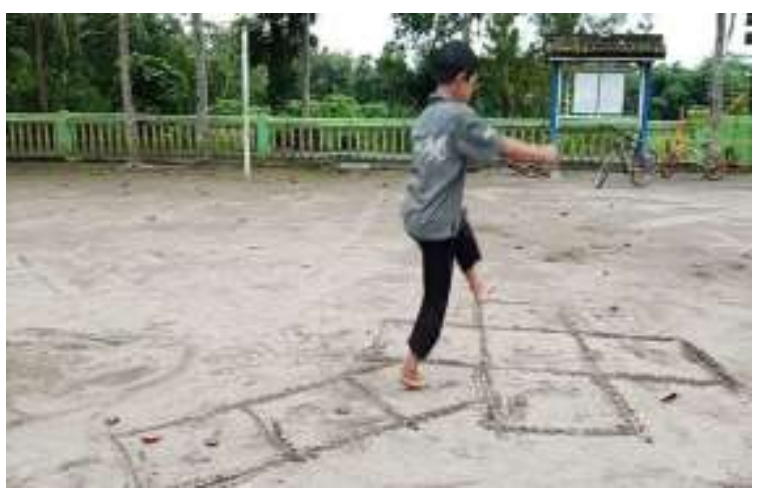

Figure 3 Children Playing Propellers Engklek.

The propeller Engklek looks like a propeller. This Engklek game can be used as an ethnomathematical object by modifying the image without losing the ethnomathematical characteristics [10]. Here is a picture of a propeller-modified Engklek. 


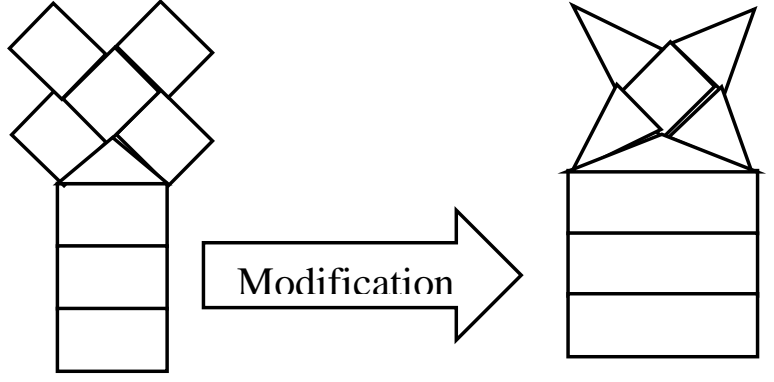

Figure 4 Airplane Engklek..

Figure 4 shows that the image is modified by changing the shape of the propeller head on the Engklek which aims as a first step in determining the surface area of a rectangular pyramid through the propeller Engklek (Engklek head).

Efforts to improve achievement and maintain a local culture in the student learning process by making worksheet-based ethnomathematics, because existing and used worksheet in schools tend to use published worksheet, where the presentation is mathematical and procedural. Such worksheet can provide a less new learning experience for students [8]. Thus, students do not understand other mathematical knowledge and are less able to connect with examples of application in the real world, especially in the culture in the surrounding environment [9]. Therefore, worksheet are needed that can make it easier for students to learn cubes and rectangular pyramids based on ethnomathematics. With this worksheet, it is hoped that students can learn while playing so it is easy to understand the material. This study aims to describe the process and result of the development of student's worksheet based on ethnomathematics traditional Engklek game on cube and rectangular pyramid.

\section{METHODS}

The type of research used is the development (Design and Development) with the development model of Plomp (2013), namely (1) Initial Investigation, (2) Design, (3) Realization, (4) Test, Evaluation, and Revision, (5) Implementation. However, the implementation stage was not carried out because this research was focused on producing a final prototype that was ready to be implemented. The final prototype was only tested to assess the validity, practicality, and effectiveness of the worksheet developed on limited subjects consisting of class 8th students with 5 (five) students as limited trial subjects. Data research techniques in this study, namely: (1) validation of worksheet assessment, (2) observation, (3) giving questionnaires, (4) giving the test. The following is a development flowchart in this research [7] (Figure 1)

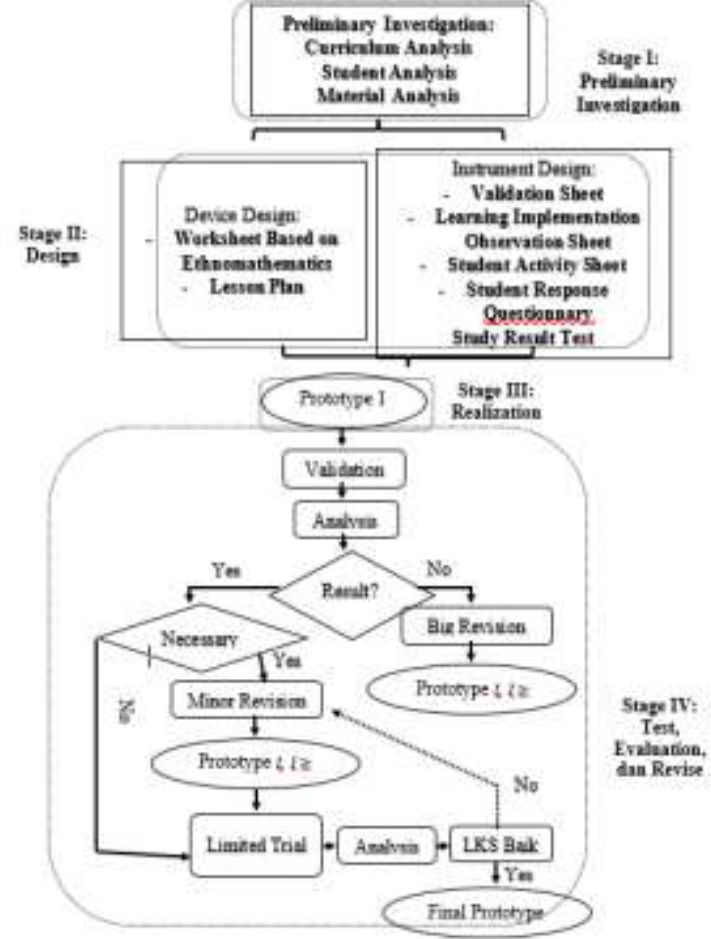

Figure 5 Plomp Development Flowchart.

The initial investigation was carried out to analyze the problems and needs that exist in the development of ethnomathematics-based worksheet, namely by analyzing the curriculum, students, and materials. At the design stage, the researchers compiled an ethnomathematical-based worksheet on the flat-sided geometric material by designing research instruments, namely validation instruments, expert statement sheets for practicality, learning implementation sheets and student activity observation sheets, learning outcomes ice sheets, and student response questionnaires. for effectiveness, Ethnomathematics-based worksheet, and lesson plans.

In the realization stage, the ethnomathematics-based worksheet is made intact, and the results of this development are called prototype I. Next, the test, evaluation, and revision stages are carried out. At this stage, the final prototype of the ethnomathematics-based worksheet will be obtained. At this stage, validation activities and limited testing of the prototype I were carried out at the realization stage. Limited trial activities were carried out to determine the practicality of ethnomathematical-based worksheet on flat-sided building materials. The criteria that must be met are the teacher managing learning, student activities, student responses, and valid worksheet. Limited trials were carried out on $8^{\text {th }}$-grade students as many as 5 (five) students. The results of the trial are in the form of research data which will then be analyzed, resulting in a research report. 
At the implementation stage, solutions have been developed to deal with problems and then set out on the actual problem situation. However, in this study, the implementation phase was not carried out because this research focused on producing a final prototype that was ready to be implemented. The final prototype was only tested to assess the validity, practicality, and effectiveness of the worksheet developed on limited subjects so that the development of the Plomp model used four modified stages.

This research refers to development research using the Plomp model because the stages in the Plomp development research are following the development of ethnomathematical-based worksheet, and there are stages of testing, evaluation, and revision so that researchers can present valid and practical ethnomathematical-based worksheet.

\section{RESULTS AND DISCUSS}

\subsection{Initial Investigation Stage}

\subsubsection{Curriculum Analysis}

Basic Competencies and Competency Achievement Indicators concerning the 2013 Revised Curriculum following the curriculum that is being used in public schools, so researchers make a worksheet that is following Basic Competencies 3.9 (Distinguishing and determining the surface area and volume of the flatsided shape) and Competency Achievement Indicators (Determining the surface area of the cube and rectangular pyramid from the net) by including the ethnomathematics activities that have been determined in the developed student worksheet, namely playing activities, building activities, measuring activities, and activities explain.

\subsubsection{Analysis of Research/Students}

The $8^{\text {th }}$-grade students already know and study the triangles and rectangles in class $7^{\text {th }}$ Even Semester. The triangles and rectangles are prerequisite materials needed to learn to build flat-sided spaces.

\subsubsection{Material Analysis}

The material chosen in this study is a flat side space with conditions only on the material of the cube and rectangular pyramid. Students who are research subjects have received the prerequisite material, namely triangles and rectangles. Based on the selected material, the researcher chose the traditional Engklek game as an ethnomathematical object, where the airplane Engklek game is in a cube net, and the head of the propeller Engklek head is in a rectangular pyramid net.

\subsection{Design Stage}

The design stage in this study was carried out as an initial step for the solution at an early stage. The design in this study focuses on developing student worksheet based on the ethnomathematics of traditional Engklek games on rectangular cubes and rectangular pyramids

\subsubsection{Worksheet Design}

The initial planning of the design of the Junior High School worksheet based on the traditional ethnomathematics Engklek game on the material of cubes and rectangular pyramids that will be developed by the researcher consists of closing sections containing: (1) the title of the worksheet, the title of the worksheet adjusted to the material being discussed, (2) the identity of students/groups, contains the name of the group and group members, and (3) on the cover part will also be embedded with a background in the form of an ethnomathematics object to beautify the appearance as well as describe the essence of the worksheet. The following is a picture of the cover design for the worksheet to be developed (Figure 5).

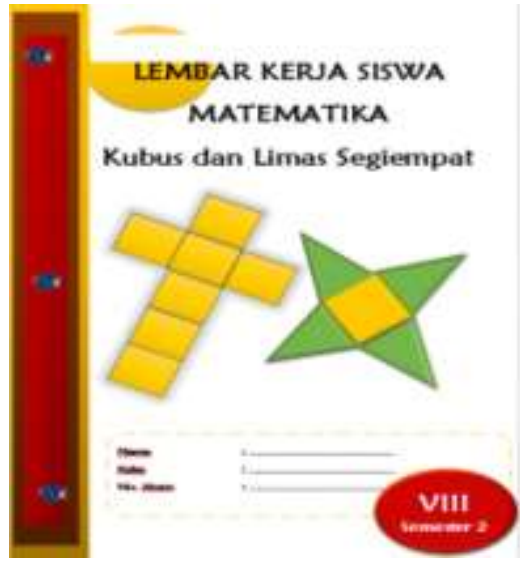

Figure 6 The cover design of the worksheet.

Furthermore, in the contents of the worksheet (Context Worksheet), contains: (1) Basic Competence and competency indicators and learning objectives, (2) instructions for using worksheet (Figure 7), (3) introductory material, contains brief information about the material to be, (3) Supporting information, containing additional information that will become a reference in the formulation of problems, for example information about ethnomathematics objects, and (4) Material with activity steps, namely student activities to understand the concept of material being studied through the stages of ethnomathematics activities, namely: Playing activities, in this activity students help the form of ethnomathematical objects, wake-up activities, in this activity students draw, determine, and determine it into a flat side space, measuring activities, activities in this activity students will determine the 
concept, and explain, in this activity students will conclude from the activity of determining the concept that has been carried out (Figure 8).

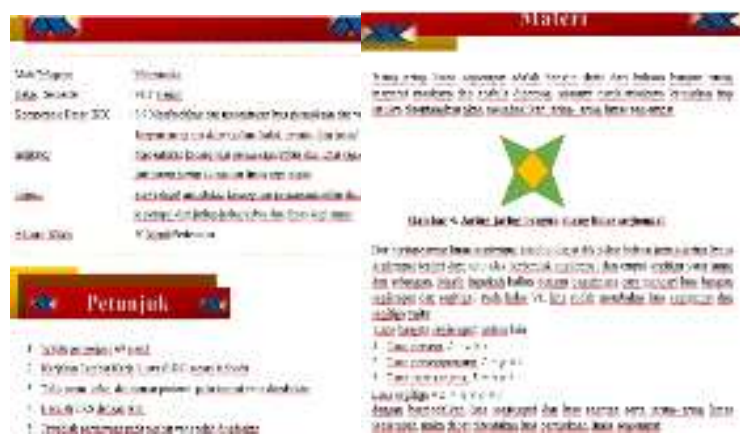

Figure 7 Instructions and material design.

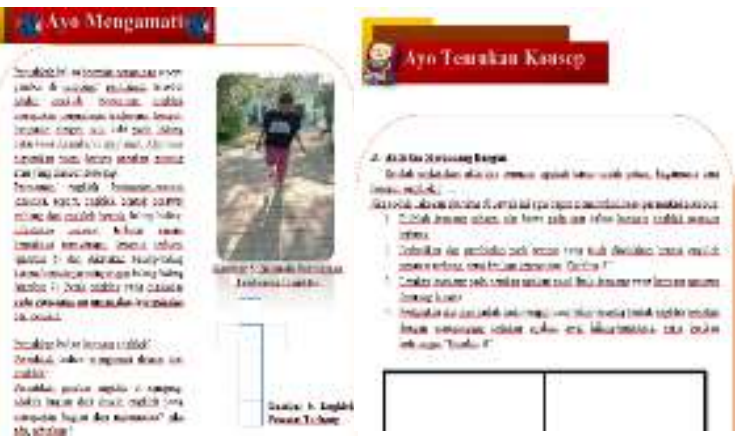

Figure 8 Introductory material and activity design.

Next, contains Exercise questions, to train students' understanding of the material that has been studied and the concepts that have been discovered by students through activities on the worksheet.

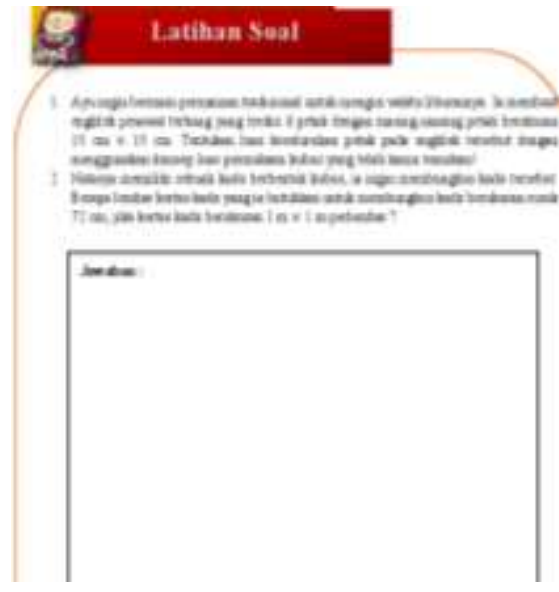

Figure 9 Design Exercise Problem.

\subsubsection{Design of Learning Outcomes Test}

This learning outcome test is used as an instrument to measure the effectiveness of student worksheet. Learning outcome tests are arranged based on a grid of learning outcome test questions, where the questions are in the form of a description consisting of 6 contextual questions.

\subsubsection{Assessment Instrument Design}

The instrument for measuring the validity of the worksheet is designed into two, namely for material experts based on the feasibility of content aspects and for linguists based on format and language aspects. The instrument for measuring the practicality of the worksheet is designed into two, namely the practicality report sheet for teachers and students. Instruments to measure the effectiveness of student worksheet in the form of student response questionnaires and learning outcomes tests.

\subsection{Realization Stage}

This stage is a follow-up to the previous design stage. The results of the realization stage are worksheet junior high school based on ethnomathematics of traditional Engklek games and the necessary research instruments. The student worksheet from the realization stage is called prototype I. Below is an excerpt from the student worksheet based on the ethnomathematics of traditional Engklek games on the material of cubes and rectangular pyramids.
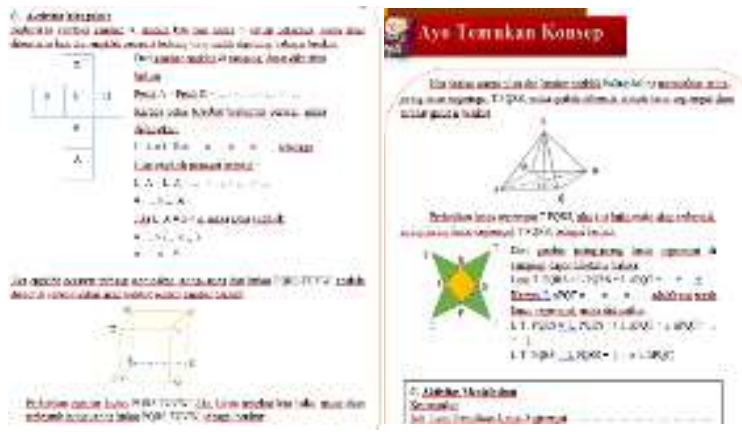

Figure 10 Worksheet Based Ethnomathematics .

The prototype I The ethnomathematics-based worksheet has a cover that includes the material to be studied. In the beginning, it contains core competencies, indicators, and instructions for using the Worksheet. There is a description of the material regarding the nets of cubes and rectangular pyramids, while the introduction contains an introduction to students in the Engklek game in the "Let's Observe" phase. The prototype I worksheet produced at the design stage was subjected to legibility testing on five research subjects and revision of several parts of the worksheet, especially in terms of typing errors and inappropriate use of bold and italic letters, and the absence of page numbers on the worksheet.

\subsection{Test, Evaluation, and Revision Stage Realization Stage}

At this stage, there are two main activities carried out, namely validation of worksheet to experts and limited trials. Worksheet validated to linguists and 
material experts. The worksheet developed was validated by one lecturer at the STKIP PGRI Sidoarjo, Indonesia Mathematics Education Program and one mathematics teacher at one of the Junior High Schools in Sidoarjo, Indonesia who acted as material experts and one lecturer from the Primary School Education Program and a mathematics teacher at one of Junior High Schools in Sidoarjo, Indonesia who acted as linguists. The recapitulation result of each validator can be seen in Table $\mathbf{1}$ as follows:

Table 1. Recapitulation of Expert Assessment Results

\begin{tabular}{|c|r|l|r|l|}
\hline Expert & $\begin{array}{c}\text { Score } \\
\text { Average } \\
\text { for each } \\
\text { aspect } \\
\left(A_{i}\right)\end{array}$ & & $\begin{array}{c}\text { Average } \\
\text { total } \\
\text { validity } \\
(R T V)\end{array}$ & Category \\
\hline $\begin{array}{c}\text { Material } \\
\text { Expert }\end{array}$ & 4.25 & & 4.27 & $\begin{array}{l}\text { Very } \\
\text { Valid }\end{array}$ \\
\hline Lingui & 4.29 & & & \\
\hline
\end{tabular}

Based on the results of the analysis of the results of the validity of the student worksheet by the experts, it gets an average score of 4.27 which is categorized as very valid and feasible to be tested with several suggestions as a basis for revision. After the student worksheet is declared fit for testing with revisions by material experts and linguists, the worksheet can be tried out. The trial was carried out in a group consisting of five students.

The practicality of the student worksheet that has been developed can be known in theory and practice. In theory, the validator statement on the validation sheet states that the student worksheet can be used with minor revisions. The results of the validators' statements can be seen in Table 2 as follows:

Table 2. Practical Data Descriptions of Worksheet in

\begin{tabular}{|c|c|l|}
\hline No & Validator & \multicolumn{1}{|c|}{ Information } \\
\hline 1 & $\begin{array}{c}\text { Lecturer } \\
\text { Validator 1 }\end{array}$ & $\begin{array}{l}\text { It is worth testing it in } \\
\text { the field with minor } \\
\text { revisions }\end{array}$ \\
\hline 2 & Lecturer & $\begin{array}{l}\text { It is worth testing it in } \\
\text { the field with minor } \\
\text { revisions }\end{array}$ \\
\hline 3 & Tealidator 2 & $\begin{array}{l}\text { It is worth testing it in } \\
\text { the field with minor } \\
\text { revisions }\end{array}$ \\
\hline
\end{tabular}

Theory
The research was conducted with research conducted by Ervina, et al. (2019) [2], that the student worksheet developed are following practical criteria, in theory, if the developed worksheet can be used with a little revision through statements on validation sheets that have been validated by validators In addition, the practical worksheet can be accessed by teachers and students can easily use worksheet developed through the management of learning and student activities carried out during two meetings [2]. The description of result percentage learning management observation can be seen in Table 3 as follows:

Table 3. Description of Results Percentage (\%) Learning Management Observation

\begin{tabular}{|c|c|c|}
\hline \multirow{2}{*}{ Description } & \multicolumn{2}{|c|}{ Implementation } \\
\cline { 2 - 3 } & 1st meeting & 2nd meeting \\
\hline $\begin{array}{c}\text { Number of phases } \\
\text { carried out }\end{array}$ & 16 & 15 \\
\hline $\begin{array}{c}\text { Percentage of } \\
\text { Implementation (\%) }\end{array}$ & $\mathbf{8 8 . 9 \%}$ & $\mathbf{8 3 \%}$ \\
\hline
\end{tabular}

The description of the results of the observation of learning management shows that the number of phases carried out at the 1 st meeting was 16 phases $(88.9 \%)$ of the 18 phases, while the number of phases carried out at the second meeting was 15 phases $(83 \%)$ out of 18 a planned phase. With the end of the implementation of learning using student worksheet based on ethnomathematics, the traditional game of Engklek on the material of rectangular cubes and rectangular pyramids is said to be practical to use, because the proportion of implementation is $>75 \%$.

Based on the results of the observation of learning management, the analysis of the results of the learning management assessment can be described in Table $\mathbf{4}$ as follows:

Table 4. Description of Assessment Result Analysis Learning Management

\begin{tabular}{|c|c|c|c|}
\hline \multirow{2}{*}{ Activities } & \multicolumn{2}{|c|}{$\begin{array}{c}\text { Average of each } \\
\text { activity }\left(K_{i}\right)\end{array}$} & \multirow{2}{*}{$\begin{array}{c}\text { Average } \\
\text { performance } \\
(R K)\end{array}$} \\
\hline & $\begin{array}{l}\text { 1st } \\
\text { meeting }\end{array}$ & $\begin{array}{l}\text { 2nd } \\
\text { meeting }\end{array}$ & \\
\hline preliminary & 3.00 & 2.60 & 2.80 \\
\hline Core & 3.90 & 3.81 & 3.85 \\
\hline Closing & 4.00 & 3.33 & 3.67 \\
\hline \multicolumn{3}{|c|}{ Final Average } & 3.44 \\
\hline
\end{tabular}

The description of the analysis of the learning management results shows $R K$ the lowest was in the preliminary activities, namely 2.80 , while the highest was in the core activities. In learning management, the final average is 3.44 or included in the good criteria 
$(3.40<\leq 4.20)$. Here's an Engklek game to learn the cube and the rectangular pyramid (Figure 11)

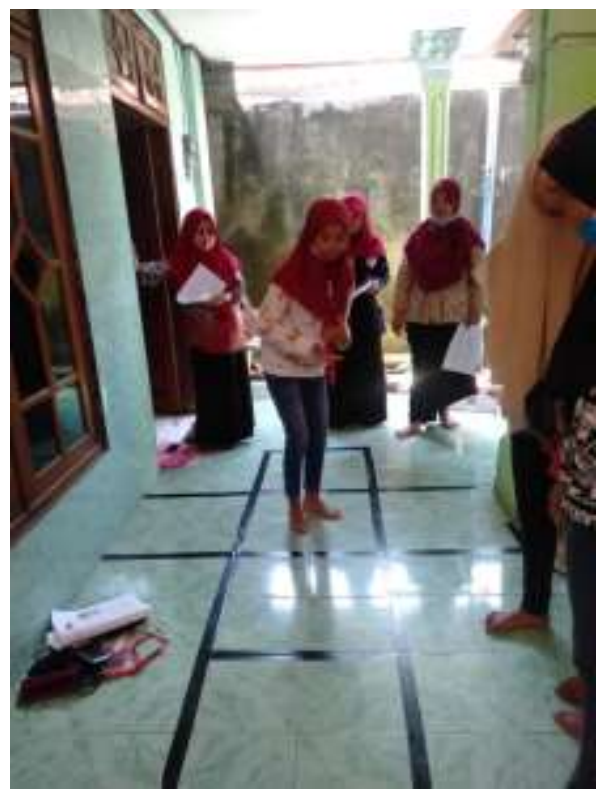

Figure 11 Engklek Game.

Observation of student activities towards learning using student worksheet based on ethnomathematics traditional Engklek game was carried out by two observers in 2 meetings. The resulting student activity categories can be seen in Table $\mathbf{5}$ as follows:

Table 5. Student Activity Categories

\begin{tabular}{|c|c|c|c|}
\hline Category & $\begin{array}{l}\text { Forms of } \\
\text { Student } \\
\text { Activity }\end{array}$ & Percentage & $\begin{array}{c}\text { Total } \\
\text { Percentage } \\
\text { of Each } \\
\text { Category }\end{array}$ \\
\hline \multirow{6}{*}{ Active } & 1 & $24.6 \%$ & \\
\hline & 2 & $15.2 \%$ & \\
\hline & 3 & $22.3 \%$ & \\
\hline & 4 & $13.7 \%$ & \\
\hline & 5 & $9.8 \%$ & \\
\hline & 6 & $6.2 \%$ & \\
\hline Passive & 7 & $8.2 \%$ & $8.2 \%$ \\
\hline
\end{tabular}

Based on table $\mathbf{5}$, it can be seen from the active activity in learning with a $92.8 \%$ greater presentation that it can display passive activity, which is $8.2 \%$. These data indicate that more students are active in learning using worksheet that has been developed by researchers so that they can prove that the traditional game ethnomathematics-based worksheet on cube and rectangular pyramid material is practically used [12].

The effectiveness of the developed student worksheet can be seen from the results of student learning tests and student responses. The results of

\begin{tabular}{|c|c|c|c|c|c|}
\hline \multirow{2}{*}{ Question to } & \multicolumn{5}{|c|}{ Percentage RS (\%) } \\
\cline { 2 - 6 } & SS & S & R & TS & STS \\
\hline 1 & 0 & 0 & 0 & 60 & 40 \\
\hline 2 & 60 & 40 & 0 & 0 & 0 \\
\hline 3 & 20 & 80 & 0 & 0 & 0 \\
\hline 4 & 0 & 0 & 0 & 60 & 40 \\
\hline 5 & 40 & 60 & 0 & 0 & 0 \\
\hline 6 & 40 & 60 & 0 & 0 & 0 \\
\hline 7 & 0 & 0 & 20 & 80 & 0 \\
\hline 8 & 60 & 40 & 0 & 0 & 0 \\
\hline 9 & 40 & 60 & 0 & 0 & 0 \\
\hline 10 & 0 & 0 & 0 & 40 & 60 \\
\hline Average & & & & & \\
\hline $\begin{array}{c}\text { Percentage } \\
\text { RS (\%) }\end{array}$ & 26 & 34 & 2 & 24 & 14 \\
\hline
\end{tabular}

student learning tests can be seen in Table $\mathbf{6}$ as follows:

Table 6. Student Learning Test Results

Based on the results of the learning outcomes test it is known that the average is 88. Student learning outcomes completeness is $80 \%$ (effective) or as many as 5 (five) students who complete the 5 (five) students who take the test.

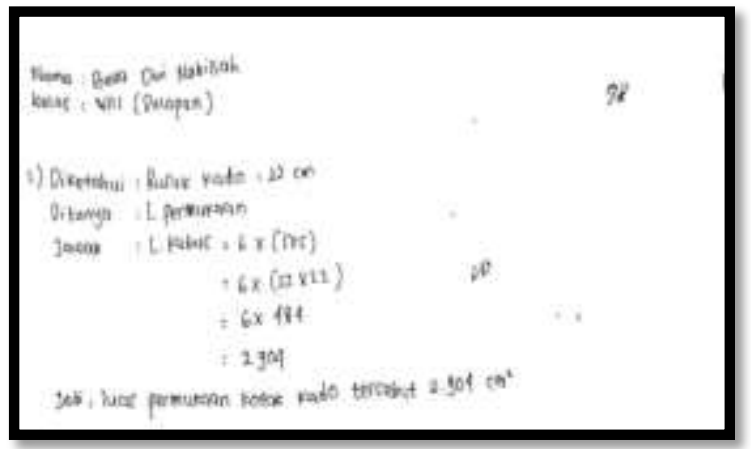

Figure 12 Student Response.

After conducting a test of learning outcomes, the researcher asked students to fill out a student response questionnaire. This student response questionnaire aims to reinforce the effectiveness of the developed worksheet. The description of student response result analysis can be seen in Table 7 as follows. 
Table 7. Description of Student Response Result Analysis

\begin{tabular}{|c|c|c|c|c|c|c|c|c|}
\hline \multirow{2}{*}{$\begin{array}{c}\text { Stude } \\
\text { nts }\end{array}$} & \multicolumn{6}{|c|}{ Score Obtained } & \multirow{2}{*}{$\begin{array}{l}\mathrm{T} \\
\text { ot } \\
\text { al }\end{array}$} & \multirow[b]{2}{*}{ Note } \\
\hline & 1 & 2 & 3 & 4 & 5 & 6 & & \\
\hline BDS & 10 & 10 & 15 & 18 & 20 & 25 & 98 & Done \\
\hline DDJ & 10 & 10 & 15 & 20 & 18 & 22 & 95 & Done \\
\hline ISM & 10 & 10 & 12 & 15 & 20 & 20 & 87 & Done \\
\hline NY & 10 & 10 & 13 & 15 & 15 & 20 & 83 & Done \\
\hline SA & 10 & 2 & 12 & 15 & 20 & 15 & 74 & $\begin{array}{c}\text { Not } \\
\text { Comple } \\
\text { ted }\end{array}$ \\
\hline \multicolumn{8}{|c|}{ Average } & 88 \\
\hline \multicolumn{8}{|c|}{ The highest score } & 98 \\
\hline \multicolumn{8}{|c|}{ Lowest Value } & 74 \\
\hline \multicolumn{8}{|c|}{ Classical Completeness (4/5 x 100\%) } & $80 \%$ \\
\hline
\end{tabular}

The table shows that the percentage of student responses based on students who choose the positive answer category is $98 \%$ ( $>>80 \%$ ) of students responding in the very positive category, so it can be said that Student Worksheet based on the ethnomathematics of traditional Engklek games is effectively used.

The ethnomathematics-based junior high school worksheet of the traditional Engklek game that has been developed has good quality because they meet three aspects, namely very valid, practical, and effective. Thus, it can be interpreted that the worksheet developed by relating everyday life is more valid, practical, and effective, this statement is in line with Rhaudah's opinion (2017) that learning using daily life-based worksheet will produce more worksheet that is more effective. valid, practical, and effectively used by students and teachers [11].

\section{CONCLUSION}

We concluded that student worksheet based on ethnomathematics traditional Engklek games on cube and rectangular pyramid that has been developed with good quality because it fulfills three aspects, namely very valid, practical, and effective so that student worksheet based on traditional Engklek ethnomathematics games on cube and pyramid material is ready to be implemented. Limited trials were not carried out in schools due to the Covid-19 pandemic and which was originally planned to be carried out on 36 students, could only be carried out with five students. Researchers hope that teachers can develop ethnomathematical-based worksheet products with wider coverage of other materials. For other researchers, researchers hope not only to stop at the test, evaluation, and revision stages but can apply the implementation stage so that the results of the work developed are more perfect.

\section{AUTHORS' CONTRIBUTIONS}

All authors planned, structured, and designed the study. Mar'atus Sholihah collected the data, analyzed the data, and wrote a paper. Soffil Widadah analyzed the data, finalized the manuscript, and proofread Dewi Sukriyah makes instruments and collected the data. All authors played a role in revising the manuscript. All authors agree to the final manuscript and are willing to take responsibility for the research that has been carried out.

\section{ACKNOWLEDGMENTS}

The authors expresses his gratitude to the head of the STKIP PGRI Sidoarjo who has motivated the authors to carry out this study.

\section{REFERENCES}

[1] R.N. Auliya, "Kecemasan Matematika dan Pemahaman Matematis", Formatif: Jurnal Ilmiah Pendidikan MIPA, 6 (1) (2016). DOI: http://dx.doi.org/10.30998/formatif.v6i1.748

[2] R.H. Ervina, S. Widadah, E.N.S. Agustina, "Pengembangan Media Pembelajaran "Karjo Suwatri" Untuk Siswa Sekolah Menengah Atas", SIGMA: Kajian Ilmu Matematika, 5(2) 85-90 (2019). URI: https://repository.stkippgrisidoarjo.ac.id/id/eprint/861

[3] D.C. Saputra, M. Marsigit, "Pengembangan Bahan Ajar Berbasis Etnomatematika Untuk Meningkatkan Prestasi Dan Motivasi Belajar Siswa SMP”, Jurnal Pendidikan Matematika-S1, 5(1) (2016).

[4] I, Muzdalipah, E. Yulianto, "Pengembangan desain pembelajaran matematika untuk siswa SD berbasis aktivitas budaya dan permainan tradisional masyarakat Kampung Naga", Jurnal Siliwangi: Seri Pendidikan 1(1)

(2015). DOI: https://doi.org/10.37058/jspendidikan.v1i1.18

[5] M. Rosa, D. C. Orey, "Humanizing mathematics through ethnomodelling", Journal of Humanistic Mathematics, 6(2), 3-22 (2016). DOI: 10.5642/jhummath.201602.03

[6] R. Nurhadi, "Basis of National Education Philosophy (Study of Educational Thought $\mathrm{Ki}$ Hadjar Dewantara, KH.A. Dahlan, and K, H. Hasyim Ashari”, Jurnal Pendidikan Surya Edukasi, $1(1)$

DOI: https://doi.org/10.37729/jpse.v1i1.2853 
[7] T. Plomp, N. Nieveen, Educational design research, Dutch Institute for Curriculum Development (SLO), 2013.

[8] U. D'Ambrósio, Ethnomathematics: Link between traditions and modernity, Sense Publizer 2006.

[9] Y. d'Entremont, "Linking mathematics, culture and community. Procedia-Social and Behavioral Sciences", 174 2818-2824 (2015). DOI: https://doi.org/10.1016/j.sbspro.2015.01.973

[10] G. Gultrom, Permainan Tradisional Anak-anak \| Engklek, (2019), Accessed: 15 November 2021, URL: https://youtu.be/M7HYJzUILXE

[11]S. Supriadi, "Didactic Design of Sundanese Ethnomathematics Learning for Primary School Students", International Journal of Learning, Teaching and Educational Research 18(11) 154-175 (2019). DOI: https://doi.org/10/26803/ijlter.18.11.9

[12] M.D. Mumford, V. Giorgini, C. Gibson, J. Mecca, "Creative thinking: Processes, strategies, and knowledge. In Handbook of research on creativity. Edward Elgar Publishing", (2013). DOI: https://doi.org/10.4337/9780857939814 